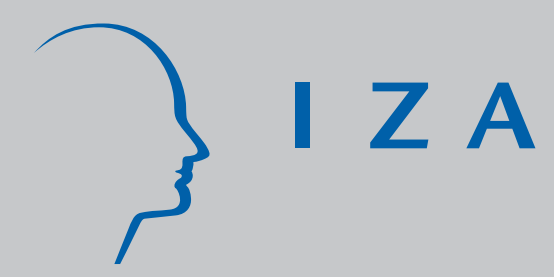

IZA DP No. 4013

Labour Market Effects of the Polytechnic Education Reform: The Finnish Experience

Petri Böckerman

Ulla Hämäläinen

Roope Uusitalo

February 2009 


\title{
Labour Market Effects of the Polytechnic Education Reform: The Finnish Experience
}

\author{
Petri Böckerman \\ Labour Institute for Economic Research \\ Ulla Hämäläinen \\ The Social Insurance Institution of Finland \\ Roope Uusitalo \\ Government Institute for Economic Research (VATT), \\ IFAU and IZA
}

\author{
Discussion Paper No. 4013 \\ February 2009
}

\author{
IZA \\ P.O. Box 7240 \\ 53072 Bonn \\ Germany \\ Phone: +49-228-3894-0 \\ Fax: +49-228-3894-180 \\ E-mail: iza@iza.org
}

\begin{abstract}
Any opinions expressed here are those of the author(s) and not those of IZA. Research published in this series may include views on policy, but the institute itself takes no institutional policy positions.

The Institute for the Study of Labor (IZA) in Bonn is a local and virtual international research center and a place of communication between science, politics and business. IZA is an independent nonprofit organization supported by Deutsche Post Foundation. The center is associated with the University of Bonn and offers a stimulating research environment through its international network, workshops and conferences, data service, project support, research visits and doctoral program. IZA engages in (i) original and internationally competitive research in all fields of labor economics, (ii) development of policy concepts, and (iii) dissemination of research results and concepts to the interested public.
\end{abstract}

IZA Discussion Papers often represent preliminary work and are circulated to encourage discussion. Citation of such a paper should account for its provisional character. A revised version may be available directly from the author. 


\section{ABSTRACT \\ Labour Market Effects of the Polytechnic Education Reform: The Finnish Experience ${ }^{*}$}

This paper evaluates the labour market effects of the introduction of the polytechnic education system in Finland. The polytechnic reform gradually transformed former vocational colleges into polytechnics. Since the timing of the reform differed across schools, we can compare the performance of polytechnic graduates to the performance of vocational college graduates controlling for both the year and the school effects. The results are somewhat sensitive to how the selectivity issues are treated but generally suggest that both the earnings and the employment levels of post-reform graduates are higher in the field of business and administration. The effects are much smaller and usually insignificant in other fields.

JEL Classification: $\quad 121,123$

Keywords: vocational education, polytechnic education, school reform, return to education

Corresponding author:

Petri Böckerman

Labour Institute for Economic Research

Pitkänsillanranta 3A, 6. krs.

FI-00530 Helsinki

Finland

E-mail: petri.bockerman@labour.fi

\footnotetext{
* This study has been financed by the Ministry of Education. The authors would like to thank two anonymous referees for valuable comments, which have greatly improved the paper. Paul A. Dillingham has kindly checked the English language. The usual disclaimer applies.
} 


\section{Introduction}

This paper evaluates the labour market effects of the introduction of the polytechnic education system in Finland that took place in the 1990s. The polytechnics constitute a new non-university sector in Finnish higher education and they were established side by side with the existing universities. The reform gradually transformed former vocational colleges into polytechnics.

Important non-university higher education sectors exist in most OECD countries. Typically these programs offer a wide spectrum of vocational education that qualify for specific occupation or prepare for a profession. A distinguishing feature compared to the universities is that the studies are more practically oriented thus fulfilling specific needs of local economies (Kyvik, 2004). In some countries these institutions have a long history. Fachhochschulen in Germany were created already in the 1960s. Also UK had a large polytechnic sector between 1965 and 1992 (Pratt, 1997). In the US a quarter of post-secondary college students enrolled community colleges already in 1970 (Gill \& Leigh, 2000). In other countries non-university higher education sector has expanded more recently. The Dutch Hogescholen were created out of secondary schools in 1986 (OECD, 2005) and University Colleges in Norway by merging a large number of vocationally oriented colleges in 1994 (Kyvik, 2002).

The polytechnic reforms have aimed to improve the vocational skills of graduates. The overall success of the reforms should therefore be evaluated by assessing their effects on the labour market outcomes. Still many existing evaluations focus on the issues related to implementation, organization of new institutions and their status or cost- 
efficiency (e.g. Kyvik, 2002) or the graduates’ own views about the content of their jobs and placement in the labour market (Stenström, 2006; Böckerman, 2007). The OECD (2003) implemented an extensive assessment of the Finnish polytechnic reform. The only result regarding the labour market outcomes in the report is that $3.7 \%$ of the polytechnic graduates were unemployed one year after graduation in 1998. This number can be considered to be either 'low' or 'high' depending on the yardstick that is used in the comparison.

Cross-section estimates that compare the outcomes of polytechnic graduates to the labour market outcomes of graduates from other levels of education exist in several countries. Results from a European-wide survey about the placement of graduates are reported by Schomburg and Teichler (2006). The effects of non-university higher education on wages are also often reported either by allocating the students a standard length of education or by treating non-university higher education as a separate category of education (e.g. Kane \& Rouse, 1995). While these studies produce information on the labour market value of non-university higher education they are not focused on the effects of specific reforms of education systems. As in all studies on the effects of education, selectivity issues are often a major problem in these studies.

We evaluate the effects of the polytechnic reform by comparing polytechnic graduates’ annual earnings and employment levels to those who have obtained vocational college degrees in the pre-reform system. The gradual implementation of the reform offers a quasi-experimental setting where we can control for both the year and the school fixed effects. 
Our paper is related to the studies that attempt to identify the causal effects of schooling using variation in local schooling opportunities as instruments. An early example is Card (1995), who uses the distance to a college as an instrument for education. He shows that otherwise identical men who live close to a college have significantly higher education and earnings than other men. Assuming that proximity to a college has no direct effects on earnings, spatial variation in education and earnings due to differential access to college education can be used to purge the return to education estimates from the endogeneity bias.

Several more recent papers have used the changes in schooling opportunities to identify the returns to schooling. For example, Margo and Finegan (1996) exploit the cross-state and cross-time variation in compulsory schooling laws in order to estimate the returns to education. Harmon and Walker (1995) utilise the change in the minimum schoolleaving age as a source of exogenous variation in educational attainment to estimate the economic return to education in the UK. Meghir and Palme (1999; 2005) estimate the return to schooling in Sweden, exploiting variation in the length of schooling due to gradual implementation of the nine-year comprehensive school system in the 1950s. Maurin and McNally (2007) analyse the effects of a natural experiment in which there was a widening access to the more academic track in Northern Ireland. While most of these studies measure the effects of years of education there is nothing fundamentally different in measuring the effects of discrete changes in school systems such as upgrading vocational colleges into polytechnics.

One of the main differences between our study and the studies based on compulsory school reforms is that the polytechnic reform affects much older students that are much 
more likely to move in order to attend a particular polytechnic programme. Hence, the selectivity problems are potentially more severe in our case. In addition to controlling for the permanent differences across schools, we deal with the selectivity issues by i) controlling for a wide range of observable characteristics of graduates including the grades that the vocational colleges and polytechnic schools used in their admission decisions, ii) estimating the effects of polytechnic reform using data aggregated to the school-level avoiding the selectivity into different programmes within schools, and iii) implementing an instrumental variable estimator that exploits the exogenous variation in the local supply of polytechnic education.

To preview, the most important finding is that the polytechnic education reform has increased both the earnings and the employment levels of post-reform graduates in the field of business and administration. The effects are much smaller in other fields. Even in business and administration the results are somewhat sensitive to how the selectivity of students into different schools is accounted for.

The structure of the paper is as follows. Section 2 provides a description of the Finnish education system and the polytechnic education reform. Section 3 explains our empirical approach. Section 4 introduces the data. Section 5 reports the results and the last section concludes. 


\section{The Finnish education system and the polytechnic reform}

\subsection{The Finnish education system}

Finnish children begin school at the age of seven. Compulsory comprehensive schooling lasts for nine years. ${ }^{1}$ After comprehensive schooling roughly 50 per cent of the pupils continue in the upper secondary school, which lasts for three years and ends with a matriculation examination. The remaining 45 per cent enter various vocational schools and vocational colleges whose courses last for two to three years. Consequently, 95\% of the pupils from comprehensive schools continue immediately in secondary-level education.

Vocational schools and colleges were a diverse group of schools at the beginning of 1990s. The entry requirements and the length of education varied between schools. Some took most students directly from comprehensive schools and provided them with two or three years of vocational education. In some vocational colleges most students had completed upper secondary schooling before entering vocational college. For example, a business degree from a vocational college typically required three years of schooling after comprehensive school or two years of schooling after upper secondary school. An engineering degree from a technical college required that the students had either a vocational school degree or an upper secondary school certificate before entering. Education at technical college typically took four years to complete. At nursing school most students had completed their upper secondary schooling before entering, and the vocational college courses lasted for around three years. 
The highest level of education in Finland is provided by universities. Students are directly enrolled for a Master's programme that takes, on average, five to six years to complete. The vast majority of students enter university after completing upper secondary schooling, but it is also possible to apply to a university with a vocational college degree. As a consequence of the polytechnic education reform, the higher education system nowadays comprises two parallel sectors, which are universities and vocationally-oriented polytechnics. A major difference is that polytechnic schools are not engaged in academic research like universities.

Education is free at all levels. State-financed student aid and subsidized loans make it possible to pursue education, irrespective of the family's financial circumstances. Good employment prospects for graduates and reasonably high monetary rewards from education have kept the demand for education high. The supply of education is controlled by the Ministry of Education through its decisions on the number of study places at universities and through its decisions regarding the funding of other schools. The number of applications to universities and to the most popular polytechnics exceeds the number of available places by a factor of four. Entrance exams and/or previous grades are used to select students for most schools at all levels.

\subsection{The polytechnic reform}

The most important aim of the introduction of the polytechnic education system was to respond to new demands for vocational skills that were seen to arise in the labour market (Ministry of Education, 1990). The creation of the polytechnic system meant a rapid expansion in the provision of higher education. Furthermore, the purpose of the 
reform was to raise the general educational standard and training of Finns and to diversify higher education. Other objectives included pooling resources into larger units and making the Finnish education system more comparable to educational systems in other European countries. One additional factor that influenced the introduction of polytechnic education was the rapid increase in the number of matriculated students who did not have a student place in higher education.

The first 22 polytechnics were established under a temporary licence in 1991 (e.g. Lampinen, 2004). These polytechnics were created by the merging of 215 vocational colleges and vocational schools, often operating at several locations. Seven new temporary licences were granted during the 1990s. The experimental phase was judged to be successful and since 1996 the temporary polytechnics have gradually become permanent. Currently there are 29 polytechnics.

The old college system was gradually run down within the new polytechnics. The reform was carried out by transforming the lines of study for the matriculated students in the old college system into polytechnic programmes. The students who had started their studies before a particular vocational college transformed itself into a polytechnic continued their studies in the old college lines and they eventually graduated with vocational college degrees. During the transformational period the old vocational college lines and the new polytechnic lines were run in parallel within the new polytechnics. The gradual implementation of the reform is illustrated in Figure 1. It shows the share of polytechnic graduates out of all graduates by school for the 29 newly created polytechnics over the period 1994-2000. As also shown in Figure 1 the timing 
of the reform varied across schools. We exploit this variation in timing to identify the effects of the reform.

Figure 1 around here

The polytechnics have between 600 and 6500 students each (OECD, 2003). Most polytechnic schools are multidisciplinary and the network of polytechnics covers the whole country. Indeed, one of the many goals of the polytechnic reform was to promote regional development and meet regional needs for higher education (OECD, 2003). Polytechnic degrees are Bachelor-level higher education degrees with a vocational emphasis. $^{2}$ These degrees take around 3.5 to 4 years to complete. ${ }^{3}$

The first graduates from the new polytechnics entered the labour market in 1994. The number of graduates grew rapidly and by 2000 the number of new polytechnic graduates exceeded the number of new university graduates. The three largest fields were business and administration, social and health care (typically nursing), and technology and transport (typically engineers). Each year, between eighty and ninety per cent of all polytechnic degrees were awarded in these three fields. Development of the number of degrees by field is reported in more detail in Figure 2. The field of study for each student is already determined by the time when a student applies for and is accepted for enrolment in a particular programme.

Figure 2 around here 
The reform changed the curriculum to a different extent in different fields. Our impression based on discussions with school administrators and officials from the Ministry of Education is that the changes in engineering and nursing education were relatively minor. Also, the average length of studies in these fields was unchanged. In contrast, there were substantial changes in business education. The average length of the studies increased from two years to three and a half years. The graduates received a completely new degree title (Bachelors of Business Administration, tradenomi in Finnish) that distinguished them from the earlier graduates from these schools (Diplomas in Business and Administration, merkonomi in Finnish). Our study makes no attempt to distinguish whether the effects of the reform are due to extension in the length or improvement in the quality of education.

Figure 3 reports the number of degrees by the level of education over the period 19902000. Looking across all fields, the number of graduates from secondary-level vocational education remained rather stable and the number of university degrees has increased over time. However, the main change in the distribution of the degrees is the decrease in the number of vocational college degrees and the corresponding increase in the polytechnic degrees. There were still some vocational college programmes left in 2000. These programmes are often designed for those who have not matriculated.

Figure 3 around here 


\section{Empirical approach}

A direct comparison of earnings and employment levels for polytechnic graduates and vocational college graduates is clearly not appropriate for two reasons. First, a direct comparison of the outcomes in any given year is problematic, because there are substantial permanent differences between schools. The first polytechnics were probably created from the best vocational colleges, whose graduates had relatively good labour market opportunities even before the polytechnic education reform. In crosssection estimates the effects of the polytechnic reform could not be distinguished from the differences across schools. Second, a direct comparison of polytechnic graduates and vocational college graduates within the schools over time would be problematic, because the overall labour market situation improved rapidly during the late 1990s. Hence, the vast majority of the polytechnic graduates entered the labour market in the late 1990s under much better overall demand conditions than those who had graduated with vocational college degrees in the early 1990s. For these two reasons the earnings and the employment rates of polytechnic graduates would be much higher than those of vocational college graduates even if the reform had no real effects.

To overcome these problems in identifying the labour market effects of the reform, we use a panel data approach to control for both the school and time effects. The school effects capture permanent differences across schools that might be due to, for example, differences in teacher quality or differences in the school's reputation that affects the pool of applicants. The time effects capture any changes in labour demand that affect all graduates in the same way. The effect of the reform is identified because the timing of the reform differed across schools. 
We examine the effects of the polytechnic reform on the labour market outcomes in the years immediately following the graduation year, so that we observe the students as soon as possible after graduation. Our main results are based on employment and annual earnings in year $t+1$, with $t$ indicating the graduation year. We also report results regarding employment, unemployment and the probability of continuing studies at the end of the years $t+1$ and $t+2$. We use linear OLS models in all specifications even when the dependent variables are discrete. The main motivation is that this specification is comparable with our IV approach described later. The empirical model is the following:

$y_{i j t}=\beta_{i 1}$ POLYTECHNIC $_{i j t}+\beta_{i 2}$ SCHOOL $_{i j}+\beta_{i 3} Y_{E A R}+\beta_{i 4}$ Controls $_{i j t}+\varepsilon_{i j t}$

where our variable of interest, POLYTECHNIC $i j$ is an indicator that a person $i$ has received a polytechnic degree from a school $j$ in the year $t, S C H O O L_{i j}$ is a set of school dummies, and $Y E A R_{i t}$ a set of year dummies. Other controls include additional background characteristics for graduates such as age and mother tongue. The school dummies are re-defined so that vocational colleges obtain the same values before and after their transformation into polytechnics (even though original school codes change).

In the empirical analysis we use data on those who graduated between 1994 and 2000 covering the period from the year when the first polytechnic graduates entered the labour market to the last year that we have data for. In principle, we could have included data from the pre-1994 vocational school graduates from schools that later became polytechnics but we chose to exclude them for two reasons. First, the pre-1994 graduates entered the labour market during exceptionally high unemployment in the early 1990s. Second, we have reliable information available about the continuation of 
studies only from 1995 onwards. Therefore, our estimates are based on data from the most intensive transformational period. In some schools most graduates already have a polytechnic degree at the beginning of the period, while in others the share with polytechnic degrees increases only at the end of the period.

Even after controlling for the school and year effects our estimates might be biased if the quality of graduates changed due to the reform. At least two phases of selection are possible. Even though polytechnics attract most of their students from the same region where they are located, nothing prevents students from moving in order to enrol in a particular polytechnic. Second, the probability of graduating is not likely to be a random process but determined by various background factors (e.g. Sandy et al. 2005). Additionally, this graduation probability may change when the pool of enrolled students changes. We have no data on those who drop out; only graduates are observed.

The selectivity problems are dealt in the following way. First, we limit the data to a subsample of those for whom we have data on the matriculation exam scores and include the exam score as a control variable in the equations. This is a reasonable strategy, since the polytechnic reform was targeted at matriculated students and the matriculation exam scores were the main criteria that both the vocational colleges and polytechnics used in their admission decisions. ${ }^{4}$ We also control for other observable characteristics of graduates (gender, age and its square, work experience at the time of graduation and its square, mother tongue, earlier qualifications). Second, we aggregate the data into the school level to control for the possible selectivity into different programmes within schools. Hence, we explain the average outcomes of a cohort of graduates from a certain school with the share of polytechnic graduates in this cohort exploiting variation in the 
timing of the reform across schools. Third, we use the changes in the local supply of polytechnic education as an instrument for polytechnic education, as described in detail below.

\subsection{IV approach}

To overcome the selectivity problems due to potential changes in the quality of entrants and the differences in the drop-out rates after the polytechnic reform we need an instrument that is correlated with the likelihood of obtaining a polytechnic degree but uncorrelated with the labour market outcomes. A natural candidate for an instrument is the change in the local supply of polytechnic education. Intuitively, the instrument is based on an observation that the transformation of a local vocational college into a polytechnic increases the likelihood of attending, and eventually graduating, from a polytechnic.

We have no regional information in the data, but since we observe all degrees obtained by all persons in our sample over an eleven-year period we can create quasi regions based on the student flows from each upper secondary school into further education. We select all upper secondary school graduates from the period from 1990 to 1996 and follow them up to year 2000 recording all their later degrees. This allows us to record the most common school choices of students from each upper secondary school. Typically, the most common choice is a nearby vocational college that at some point is transformed into a polytechnic. We use the mode of school choices of students from each upper secondary school to classify each upper secondary school into the "catchment area" of one of polytechnics. It should be noted that we use the school codes 
defined in the same way before and after the polytechnic reform and calculate the mode over the whole seven-year period (1990-1996) so that the reform has no effect on our definition of the catchment areas. The procedure splits the data into 27 quasi regions that we use as if they were genuine geographical units. ${ }^{5}$

Our regions naturally differ in their access to education and possibly also in the average student quality. Instead of using the regional differences in the polytechnic attendance rates as an instrument, we exploit the differences in the timing of the changes in the attendance rates across regions as an instrument. At the same time we can control for any permanent differences across regions.

We implement the estimator using the two-stage least squares approach. The equation of interest describing the effect of polytechnic education on the labour market outcomes is

$y_{i t}=\beta_{0}+\beta_{1}$ POLYTECHNIC ${ }_{i t}+\beta_{2} D_{\text {REGION }}+\beta_{3} D_{\text {YEAR }}+\beta_{4}$ Controls $_{i t}+\varepsilon_{i t}$

where the coefficient of interest is the effect of polytechnic education $\beta_{1}$. $D_{R E G I O N}$ is a full set of region dummies and $D_{Y E A R}$ a full set of dummies for the year of graduation from upper secondary school. Note that since school choices are endogenous, school dummies are not included as controls.

We instrument the polytechnic dummy by exploiting the changes in the polytechnic attendance rates across regions. The first stage regression equation is 
POLYTECHNIC $_{i t}=\gamma_{0}+\gamma_{1} D_{\text {REGION }}+\gamma_{2} D_{\text {YEAR }}+\gamma_{3}\left(D_{\text {REGION }} \times D_{\text {YEAR }}\right)+\gamma_{4}$ Controls $_{i t}+u_{i t}$

where the term $\left(D_{R E G I O N} \times D_{Y E A R}\right)$ is a full set of interactions between regions and upper secondary school graduation years that are omitted from the second-stage equation.

Our IV estimate is based on an identifying assumption that that there are no other region-specific trends in the labour market outcomes that coincide with the timing of the transformation of local vocational colleges into polytechnics. Since we have a large number of instruments this assumption can be tested with standard over-identification tests.

Another potential problem with a very large number of instruments is that these instruments may be weak, thus causing a finite sample bias in the two-stage least squares estimates. However, as we report in the results section, the excluded instruments have substantial predictive power in the first-stage equation. We could reduce the number of instruments by using, for example, the changes in the regional polytechnic attendance rates as instruments, but since these would have to be calculated as the mean attendance rates by region and year, the reduction in the number of instruments would be artificial.

\section{Data}

Our data is based on a $50 \%$ random sample of all individuals who have received a degree from any post-compulsory school in Finland over the period 1990-2000. The primary source of data is the Register of Completed Education and Degrees maintained 
by Statistics Finland. Schools report all degrees granted directly to Statistics Finland and the register has universal coverage of all degrees from all schools in Finland. Information in the register is stored at the student level and includes a unique personal identifier, a school ID, the type of school and programme, the degree title and the year in which the degree was granted. In addition, the register includes a history file that allows one to track schools when several schools are merged into one. This allows the creation of a link that enables identification of the vocational colleges that formed each polytechnic. Specifically, the link makes it possible to assign the school fixed effects to our regression models. For reasons of confidentiality the school IDs were re-coded so that the individual schools can no longer be identified.

By using personal identification codes, we have merged our sample of individuals from the Register of Completed Education and Degrees to the Employment Statistics (ES), which is essentially an annual population census. ES contains information about all employment and unemployment spells from the pension insurance funds and unemployment registers, as well as annual earnings obtained from the Finnish tax authorities. The labour market status is recorded in ES during the last week of each year. Hourly wages are not available in the tax data. Measuring earnings as annual taxable earnings is naturally problematic. Many recent graduates do not work full-time or for the whole year. To get closer to measuring the effects on wages we restrict the data to those with annual earnings of at least $8409 €^{6}$ and analyse separately the effects on employment (defined as being employed at the end of the year and having annual earnings exceeding 8409€). Imposing a lower earnings limit also avoids giving excessive weight to very low (log) earnings that may contain more measurement error. Annual earnings are deflated to 2002 by using the consumer price index. We exclude 
the self-employed, because their share is small (roughly 2\%) and their annual taxable earnings from tax registers might underestimate their true annual earnings. We also exclude those who graduate after the age of 35.

ES, which is maintained by Statistics Finland, is useful for our purposes, because it covers all sectors of the economy. Through the use of ES, individuals can also be followed over time. Time series data on individuals allow us to calculate various employment history measures at the individual level. We use this information to calculate cumulative work experience for each person at the time of graduation. Furthermore, from ES we obtain other useful background characteristics for individuals such as gender, age and mother tongue that can be used as additional control variables to account for the possible changes in graduate composition. ES data were available for the years from 1987 to 2002 .

Moreover, we have obtained data on the matriculation examination results for the persons who have graduated from upper secondary school between 1988 and 1997. The matriculation examination is a national compulsory final exam taken by all students who graduate from upper secondary school. The answers in each test are first graded by teachers and then reviewed by associate members of the Matriculation Examination Board outside the schools. The exam scores are standardized so that their distribution is the same every year. In the early 1990s, the exam included four compulsory and two optional tests. We use the sum of the best four exam scores as a measure of ability. We have also added a person's earlier qualifications from the Register of Completed Education and Degrees to our matched data. The exact definitions and the descriptive 
statistics of the individual-level variables for the whole sample are provided in the Appendix (Table A1).

One limitation of our data is that it contains a sample of individuals who are recorded to have graduated but it contains no information on those who have dropped out from polytechnics before their graduation. According to the Ministry of Education, the average annual drop-out rate between 1998 and 2000 was 8.5\% in business and administration, $6.5 \%$ in social and health care, and $7.5 \%$ in technology and transportation. These differences are not large enough to explain our estimates.

\section{Results}

The baseline estimates for the effects of the polytechnic reform on employment, unemployment and the probability of the continuation of studies after graduation are documented in Table 1. We include, in the models, all degrees from the vocational colleges that have at some point of time transformed themselves into polytechnics over the period 1994-2000. All the models are linear probability models estimated with OLS. Marginal effects from probit models would be very similar. Panel A of Table 1 shows the results for all polytechnic degrees. The following panels show our separate estimates for the three largest fields: technology and transport, social and health care, and business and administration.

The school fixed effects are highly statistically significant and they show that there are large permanent differences between schools. Furthermore, the year effects are statistically significant and they confirm the improvement of labour market conditions 
towards the end of the 1990s, as outlined earlier. The R squared of the models is low but does not differ a lot from what has been found in the earlier studies that estimate similar models for the recent graduates (e.g. Walters, 2004).

Table 1 around here

Our baseline estimates show that employment for polytechnic graduates is 13.6 percentage points higher than for vocational college graduates one year after graduation and 11.3 percentage points higher two years after graduation (Table 1 , Panel A). ${ }^{7}$ Furthermore, the results reveal that the improvement in employment for polytechnic graduates is partly driven by the decrease in the probability of being unemployed and the reduction in the probability of continuation of studies after graduation. Both of these effects are around 4-6 percentage points.

The overall estimates for all fields conceal the fact that the effects of the polytechnic reform differ substantially between the three largest fields (Table 1, Panels B-D). The reform had not much effect on the labour market outcomes in either technology and transport or social and health care (Table 1, Panels B-C). The effect of obtaining a polytechnic degree is positive on employment and negative on unemployment in both of these fields, but the quantitative magnitude of the estimates is rather small and they are, with some exceptions, not statistically significant. In contrast, in the field of business and administration the effects of the reform are overwhelmingly positive. Our point estimates show that a polytechnic degree in the field of business and administration increases the employment rate by 25 percentage points one year after graduation and 21 percentage points two years after graduation (Table 1, Panel D). As in the case of our 
overall estimates, an increase in employment among polytechnic graduates comes from the reduction in the probability of being unemployed and the decrease in the probability of the continuation of studies after graduation.

If graduates have earlier degrees, it may be difficult to say to what extent estimated returns should be allocated to different degrees. To check the robustness of the findings in this respect, we have estimated the effects on labour market status for those who do not have any previous qualifications, apart from the matriculation examination. By a wide margin, the most common previous qualification is a secondary-level vocational school qualification. However, the effects remain almost exactly the same compared with the ones that are reported in Table 1.

In Table 2 we examine the effects of the reform on employment and annual earnings. We report the results regarding the situation in the year after the graduation year $(t+1$ in the previous table). We explain the logarithm of annual earnings with the school and year effects and a polytechnic dummy. For the reasons stated in the data section our definition of employment requires that a person has annual earnings exceeding $8409 €$ and the earnings equation is estimated conditional on being employed. In Columns 2 and 4 we also include a set of control variables of graduates (gender, age and its square, work experience and its square, mother tongue and earlier qualifications) to the equations.

Table 2 around here 
Our conclusions about the labour market effects of the reform remain largely the same. In the field of technology and transport, there seem to be some positive effects from obtaining a polytechnic degree on employment (Table 2, Panel A). Surprisingly, in the field of social and health care, the reform seems to have a small negative effect on earnings (Table 2, Panel B). Most importantly, in the field of business and administration the considerable positive effects from the reform remain (Table 2, Panel C). According to Column 2 the reform increased the employment rate by $22 \%$ and according to Column 4 the reform increased the earnings of the employed by $14 \%$.

The results in Tables 1-2 already control for any permanent differences across schools and any variation over time. In Table 3 we deal with the selectivity of students into the schools. We first report results on a restricted sample of the matriculated students for whom we can control for the matriculation examination scores. Since the matriculation examination scores are the main admission criteria to the polytechnics this should remove much of the observable differences across graduates. The most interesting finding in the results (reported in Columns 1 and 4 of Table 3) compared to the earlier estimates reported in Table 2 is that the effects of the reform remain similar in the field of business and administration.

Table 3 around here

To account for the selectivity into different programmes within schools we aggregate the data into school level and estimate the regression models with school level data using the number of graduates as weights. This would be equivalent to using individuallevel data and instrumenting the polytechnic dummy with the full set of school/year 
interactions but produces standard errors that are robust to clustering within schools. The procedure fixes the bias that would be due to more able students being selected to the polytechnic lines during the transformational period of the reform when both vocational college and polytechnic lines were running in parallel. If the reform had been a "once-and-for-all" change in each school instead of being a gradual change within schools, the results would be equivalent to those presented in Table 2.

We first adjust the outcomes for other covariates by explaining employment and earnings with the same set of covariates that we used in Columns 2 and 4 of Table 2, excluding the school and year effects and the polytechnic dummy. We then take the residuals from this regression model, aggregate data into school-level averages and explain the average residuals with the school and year effects and the polytechnic dummy using weighted least squares. The results could therefore also be interpreted as the effect of the share of polytechnic graduates in a cohort on the regression-adjusted employment rates and on the average earnings of the graduating cohort.

The results for the average level of employment (i.e. the share of employed persons among those who have graduated from each school) and annual earnings are reported in Columns 2 and 5 of Table 3. The estimates are generally smaller than those calculated from individual-level data. The reform effect is very close to zero and insignificant in technology and transport, as well as in social and health care. In the field of business and administration we still find a strong effect on employment but the effect on annual earnings is no longer significant, indicating that the effect on earnings was due to selectivity into different lines within schools (Table 3, Panel C, Columns 2 and 5). 
Finally, in Columns 3 and 6 we report the results of our IV approach, described in detail in Section 3.1. The sample size is smaller, since we could use data only on those graduating from upper secondary schools between 1990 and 1996. As described earlier, we use all interactions between regions and years as excluded instruments. The number of excluded instruments is large and varies between 134 and 149 depending on the specification. (Some region/year combinations do not exist in all fields.) Despite the large number of over-identifying restrictions, the Sargan test does not reject the validity of the instruments. The instrument set also seems to have substantial explanatory power in the first-stage regressions. In all cases the null hypothesis that the instruments are jointly zero in the first-stage regression is clearly rejected by the Cragg-Donald test.

According to the IV estimates the reform had no significant effects in the fields of technology and transport or social and health care. However, both the employment and earnings effects are significant in business and administration. The magnitude of the employment effect in Column 3 is comparable to the OLS estimates in Column 1 and school-level estimates in Column 2. The earnings effect reported in Column 6 is clearly larger than the OLS or WLS estimates in Columns 4 and 5.

A possible cause of concern regarding the IV estimates is that the first-stage F-statistics is rather low, indicating that the instruments are weak and the estimates might suffer from a finite sample bias. A relatively simple solution suggested by Staiger and Stock (1997) is to construct confidence intervals based on Anderson-Rubin test that is robust to the presence of weak instruments. In our case the test is equivalent to testing the joint hypothesis that the excluded instruments are jointly equal to zero in a reduced-form equation where the outcomes are explained with all instruments and control variables. 
Unfortunately the test has low power when the number of instruments is large which in our case leads into very wide confidence intervals.

\section{Conclusions}

This paper examines the effects of the polytechnic education reform on the labour market outcomes by taking advantage of the quasi-experimental setting that emerges because of the gradual implementation of the reform. According to the results the polytechnic reform that upgraded vocational colleges to polytechnics had some positive effects on the employment and earnings of the polytechnic graduates. However, these effects are only present in the field of business and administration. Even in business and administration the results are somewhat sensitive to how the selectivity of students into different schools is accounted for. The reform had no effect on the labour market outcomes in either technology and transport or social and health care. This pattern is consistent with the fact that the polytechnic reform extended the length of education and changed its content mostly in the field of business and administration.

The estimates to the return to polytechnic education in the field of business and administration in Table 3 correspond to one and a half years of additional schooling. Our estimates on the effect of the reform on earnings range from 3 to 20 per cent depending on the specification and the sample used. Compared to the usual estimates on the return to years of schooling (around 8 per cent according to Uusitalo 1999) our estimates seem to be of comparable magnitude. However, one must bear in mind that the reform not only extended the length of education but may also have had effects on the quality. Although it is hard to distinguish, it is possible that these quality 
improvements have had an independent effect on the labour market outcomes of the graduates. 


\section{Acknowledgements}

This study has been financed by the Ministry of Education. The authors would like to thank two anonymous referees for valuable comments, which have greatly improved the paper. Paul A. Dillingham has kindly checked the English language. The usual disclaimer applies.

\section{References}

Böckerman, P. (2007). Polytechnic graduate placement in Finnish manufacturing. Journal of Education and Work, 20(1), 1-16.

Card, D. (1995). Using geographic variation in college proximity to estimate the return

to schooling. In: L. N. Christofides, Grant, E. K. \& Swidinsky, R. (Eds.): Aspects of Labor Market Behaviour: Essays in Honour of John Vanderkamp. (pp. 201-222). Toronto: University of Toronto Press.

Gill, A., \& Leigh, D. (2000). College enrollment, college major, and the gender wage gap. Industrial and Labor Relations Review, 54(1), 163-181.

Harmon, C., \& Walker, I. (1995). Estimates of the economic return to schooling for the United Kingdom. American Economic Review, 85(5), 1278-1286.

Kane, T. J., \& Rouse, C. E. (1995). Labor-market returns to two- and four-year college. American Economic Review, 85(3), 600-614. 
Kyvik, S. (2002). The merger of non-university colleges in Norway. Higher Education, 44(1), 53-72.

Kyvik, S. (2004). Structural changes in higher education systems in Western Europe. Higher Education in Europe, 29(3), 393-409.

Lampinen, O. (2004). The use of experimentation in educational reform: The case of the Finnish polytechnic experiment 1992-1999. Tertiary Education and Management, 7(4), 1573-1936.

Margo, R. A., \& Finegan, T. A. (1996). Compulsory schooling legislation and school attendance in turn-of-the-century America: A 'natural experiment' approach. Economics Letters, 53(1), 103-110.

Maurin, E., \& McNally, S. (2007). Educational effects of widening access to the academic track: A natural experiment. IZA Discussion Paper No. 2596.

Meghir, C., \& Palme, A. (1999). Assessing the effect of schooling on earnings using a social experiment. Stockholm School of Economics, Working Paper No. 313.

Meghir, C., \& Palme, A. (2005). Educational reform, ability, and family background. American Economic Review, 95(1), 414-424. 
Ministry of Education (1990). Suomen koulutusjärjestelmä, koulutuksen taso ja kehittämislinjat (In Finnish). Helsinki: Valtioneuvoston koulutuspoliittinen selonteko eduskunnalle, 22.5. 1990.

Ministry of Education (2005). OECD thematic review of tertiary education: Country background report for Finland. Helsinki: Publications of the Ministry of Education, 2005:38

OECD (2003). Polytechnic Education in Finland. Paris: OECD.

OECD (2005). Alternatives to Universities Revisited. Paris: OECD.

Pratt, J. (1997). The Polytechnic Experiment: 1965-1992. London: Society for Research into Higher Education and Open University Press.

Sandy, J., Gonzalez, A., \& Hilmer, M. J. (2005). Alternative paths to college completion: Effect of attending a 2-year school on the probability of completing a 4year degree. Economics of Education Review, 25(5), 463-471.

Schomburg, H., \& Teichler, U. (2006). Higher Education and Graduate Employment in Europe. Results from Graduate Surveys from Twelve Countries. Dordrecht: Springler.

Staiger, D., and Stock, J. (1997). Instrumental variables regression with weak instruments. Econometrica, 65(3), 557-586 
Statistics Finland (2002). Income Distribution Statistics. Helsinki: Official Statistics of Finland.

Stenström, M-L (2006). Polytechnic graduates’ working-life skills and expertise. In: P. Tynjälä, Välimaa, J. \& Boulton-Lewis, G. (Eds.): Higher Education and Working Life: Collaborations, Confrontations and Challenges. (pp. 89-102). Amsterdam: Elsevier.

Uusitalo, R. (1999). Returns to education in Finland. Labour Economics, 6(4), 569-580.

Walters, D. (2004). A comparison of the labour market outcomes of postsecondary graduates of various levels and fields over a four-cohort period. Canadian Journal of Sociology, 29(1), 1-27. 

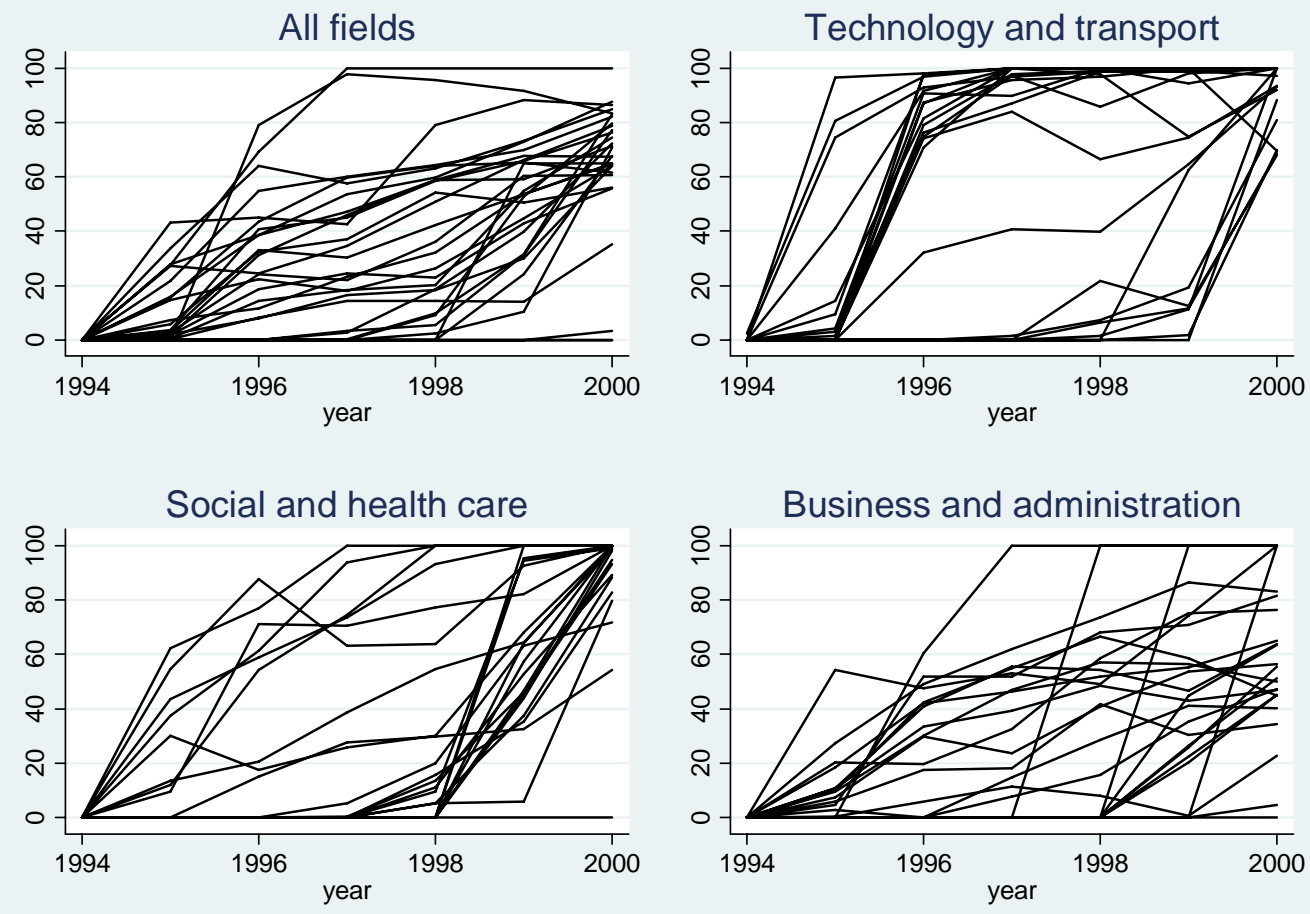

Figure 1 . The share of polytechnic graduates of all graduates at the school level over the period 1994-2000.

Source: Own calculation based a 50\% random sample from the Register of Completed Education and Degrees. 


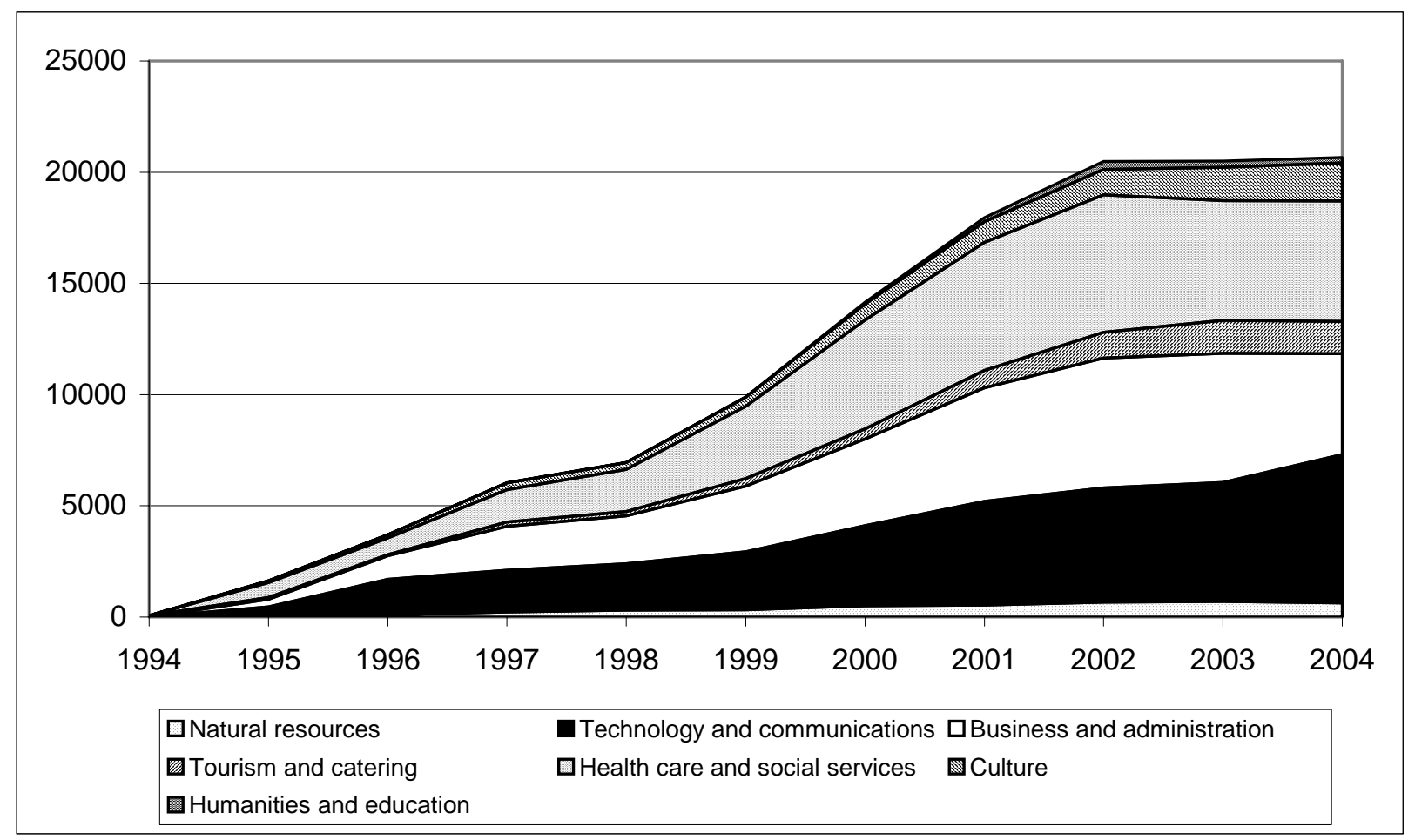

Figure 2. Polytechnic degrees by field 1994-2004.

Source: AMKOTA database by the Ministry of Education. 


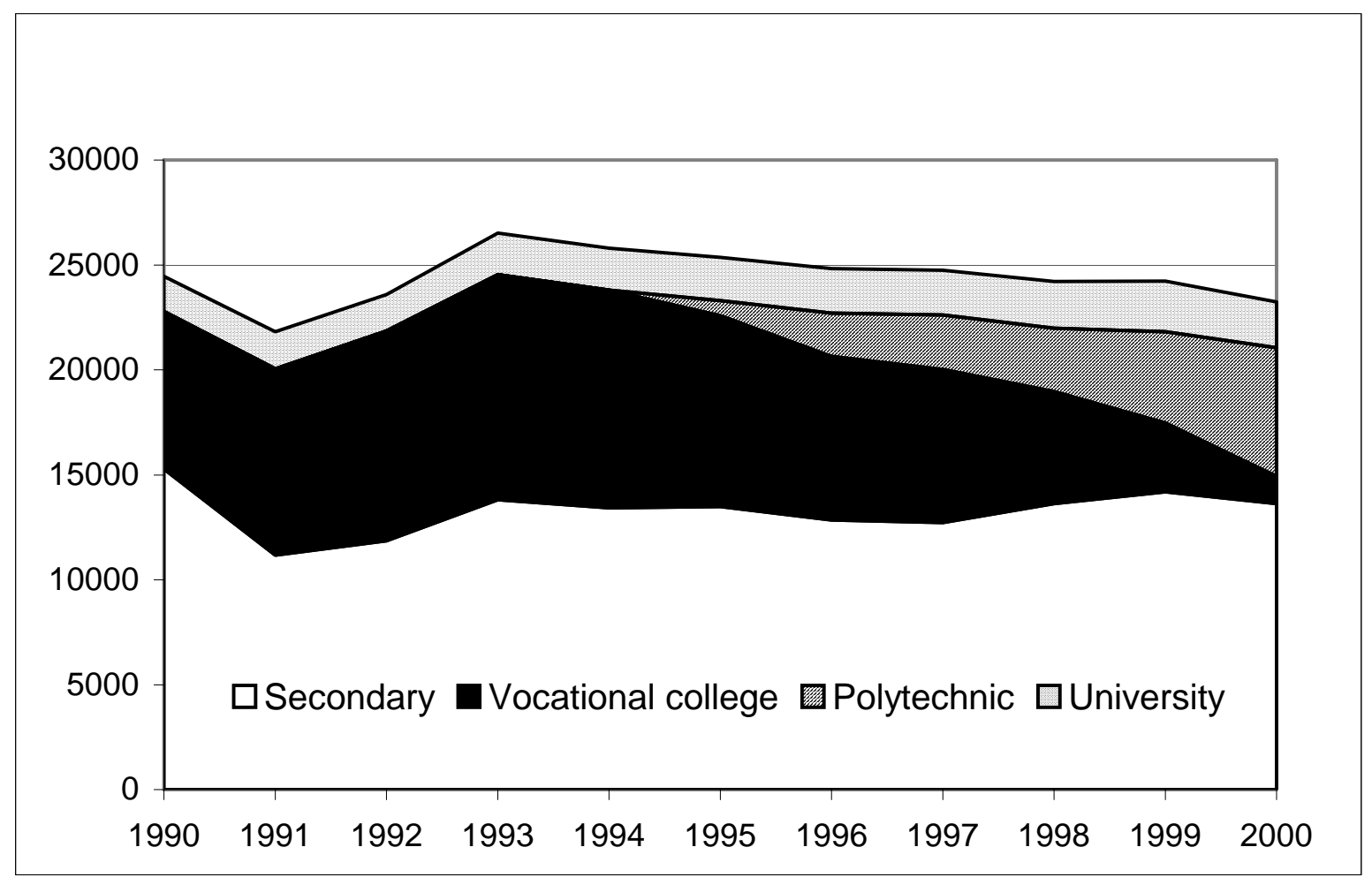

Figure 3. Degrees completed according to the level of education.

Source: Own calculation based a 50\% random sample from the Register of Completed Education and Degrees. 
Table 1 . The effect of the polytechnic reform on the labour market status.

Panel A: All fields
(1)
(2)
(3)
(4)
(5)
(6)

Employed $\mathrm{t}+1$ Employed $\mathrm{t}+2 \quad$ Unempl. $\mathrm{t}+1 \quad$ Unempl. $\mathrm{t}+2 \quad$ Student $\mathrm{t}+1 \quad$ Student $\mathrm{t}+2$

\begin{tabular}{lcccccc}
\hline POLYTECHNIC & $0.136^{* * *}$ & $0.113^{* * *}$ & $-0.056^{* * *}$ & $-0.041^{* * *}$ & $-0.059^{* * *}$ & $-0.062^{* * *}$ \\
& $(0.005)$ & $(0.005)$ & $(0.004)$ & $(0.003)$ & $(0.003)$ & $(0.003)$ \\
Sample & All & All & All & All & All & All \\
$\mathrm{N}$ & 52956 & 52956 & 52956 & 52956 & 52956 & 52956 \\
$\mathrm{R}^{2}$ & 0.045 & 0.03 & 0.033 & 0.026 & 0.016 & 0.015 \\
\hline
\end{tabular}

Panel B: Technology and transport

\begin{tabular}{lcccccc}
\hline & Employed $\mathrm{t}+1$ & Employed $\mathrm{t}+2$ & Unempl. $\mathrm{t}+1$ & Unempl. $\mathrm{t}+2$ & Student $\mathrm{t}+1$ & Student $\mathrm{t}+2$ \\
\hline POLYTECHNIC & 0.015 & $0.040^{* * *}$ & -0.009 & -0.011 & -0.007 & $-0.021^{* * *}$ \\
& $(0.013)$ & $(0.011)$ & $(0.009)$ & $(0.007)$ & $(0.009)$ & $(0.008)$ \\
Sample & All & All & All & All & All & All \\
$\mathrm{N}$ & 9298 & 9298 & 9298 & 9298 & 9298 & 9298 \\
$\mathrm{R}^{2}$ & 0.047 & 0.027 & 0.031 & 0.023 & 0.022 & 0.013 \\
\hline
\end{tabular}

Panel C: Social and health care

\begin{tabular}{lcccccc} 
& Employed $\mathrm{t}+1$ & Employed $\mathrm{t}+2$ & Unempl. $\mathrm{t}+1$ & Unempl. $\mathrm{t}+2$ & Student $\mathrm{t}+1$ & Student $\mathrm{t}+2$ \\
\hline POLYTECHNIC & $0.047^{* * *}$ & 0.018 & $-0.024^{* * *}$ & -0.013 & -0.004 & -0.003 \\
& $(0.011)$ & $(0.011)$ & $(0.009)$ & $(0.008)$ & $(0.005)$ & $(0.005)$ \\
Sample & All & All & All & All & All & All \\
$\mathrm{N}$ & 16517 & 16517 & 16517 & 16517 & 16517 & 16517 \\
$\mathrm{R}^{2}$ & 0.034 & 0.025 & 0.027 & 0.032 & 0.004 & 0.003 \\
\hline
\end{tabular}

Panel D: Business and administration

\begin{tabular}{lcccccc}
\hline & Employed $\mathrm{t}+1$ & Employed $\mathrm{t}+2$ & Unempl. $\mathrm{t}+1$ & Unempl. $\mathrm{t}+2$ & Student $\mathrm{t}+1$ & Student $\mathrm{t}+2$ \\
\hline POLYTECHNIC & $0.249^{* * *}$ & $0.213^{* * *}$ & $-0.101^{* * *}$ & $-0.079^{* * *}$ & $-0.116^{* * *}$ & $-0.118^{* * *}$ \\
& $(0.009)$ & $(0.009)$ & $(0.007)$ & $(0.006)$ & $(0.007)$ & $(0.007)$ \\
Sample & All & All & All & All & All & All \\
$\mathrm{N}$ & 20317 & 20317 & 20317 & 20317 & 20317 & 20317 \\
$\mathrm{R}^{2}$ & 0.082 & 0.062 & 0.048 & 0.036 & 0.032 & 0.029 \\
\hline
\end{tabular}

Notes: The results from separate regression models are presented in columns in which each of the dependent variables is explained with the indicators for schools and graduation years, and our variable of interest (POLYTECHNIC) that identifies a polytechnic degree. No other controls are added to the models. The estimation method is OLS in all models. Robust standard errors are reported in parentheses and significance is indicated by *** (1\%), ** (5\%), * (10\%). 
Table 2. The effect of the polytechnic reform on employment and earnings.

Panel A: Technology and transport

\begin{tabular}{|c|c|c|c|c|}
\hline & (1) & (2) & (3) & (4) \\
\hline & Employed & Employed & Earnings & Earnings \\
\hline \multirow[t]{2}{*}{ POLYTECHNIC } & 0.014 & $0.032 * *$ & -0.001 & 0.022 \\
\hline & $(0.014)$ & $(0.014)$ & $(0.014)$ & $(0.012)$ \\
\hline $\begin{array}{l}\text { Indicators for schools and } \\
\text { graduation years }\end{array}$ & Yes & Yes & Yes & Yes \\
\hline $\begin{array}{l}\text { Other background } \\
\text { characteristics }\end{array}$ & No & Yes & No & Yes \\
\hline Sample & All & All & All & All \\
\hline \multirow{2}{*}{$\begin{array}{l}\mathrm{N} \\
\mathrm{R}^{2}\end{array}$} & 9108 & 9108 & 6687 & 6687 \\
\hline & 0.056 & 0.144 & 0.096 & 0.264 \\
\hline
\end{tabular}

Panel B: Social and health care

\begin{tabular}{lcccc}
\hline & Employed & Employed & Earnings & Earnings \\
\hline POLYTECHNIC & $0.038^{* * *}$ & $0.027^{* *}$ & $-0.020^{* *}$ & $-0.024^{* * *}$ \\
& $(0.012)$ & $(0.012)$ & $(0.009)$ & $(0.009)$ \\
$\begin{array}{l}\text { Indicators for schools and } \\
\text { graduation years }\end{array}$ & Yes & Yes & Yes & Yes \\
$\begin{array}{l}\text { Other background } \\
\text { characteristics }\end{array}$ & No & Yes & No & Yes \\
Sample & All & All & All & All \\
\hline $\mathrm{N}$ & 16517 & 16517 & 9723 & 9723 \\
$\mathrm{R}^{2}$ & 0.044 & 0.089 & 0.062 & 0.170 \\
\hline
\end{tabular}

Panel C: Business and administration

\begin{tabular}{lcccc}
\hline & Employed & Employed & Earnings & Earnings \\
\hline POLYTECHNIC & $0.357^{* * *}$ & $0.217^{* * *}$ & $0.268^{* * *}$ & $0.143^{* * *}$ \\
& $(0.009)$ & $(0.011)$ & $(0.009)$ & $(0.009)$ \\
$\begin{array}{l}\text { Indicators for schools and } \\
\text { graduation years }\end{array}$ & Yes & Yes & Yes & Yes \\
$\begin{array}{l}\text { Other background } \\
\text { characteristics }\end{array}$ & No & Yes & No & Yes \\
Sample & All & All & All & All \\
\hline $\mathrm{N}$ & 20317 & 20317 & 9698 & 9698 \\
$\mathrm{R}^{2}$ & 0.132 & 0.207 & 0.244 & 0.383 \\
\hline
\end{tabular}

Notes: The results from separate regression models are presented in columns in which each of the dependent variables (the probability of being employed at $t+1$ and the logarithm of annual earnings at $t+1$ conditional on being employed is explained with the indicators for schools and graduation years, and the variable (POLYTECHNIC) that identifies a polytechnic degree. In Columns 2 and 4 other background characteristics of graduates (gender, age and its square, work experience and its square, mother tongue and earlier qualifications) are also controlled for. The estimation method is OLS in all models. Robust standard errors are reported in parentheses and significance is indicated by *** (1\%), ** (5\%), * (10\%). 
Table 3. The effect of the polytechnic reform on employment and earnings.

Panel A: Technology and transport

\begin{tabular}{|c|c|c|c|c|c|c|}
\hline & (1) & (2) & (3) & (4) & (5) & (6) \\
\hline & Employed & Employed & Employed & Earnings & Earnings & Earnings \\
\hline & $\begin{array}{c}\text { OLS } \\
\text { indiv.-level }\end{array}$ & $\begin{array}{c}\text { WLS } \\
\text { school-level }\end{array}$ & 2SLS & $\begin{array}{c}\text { OLS } \\
\text { indiv.-level }\end{array}$ & $\begin{array}{c}\text { WLS } \\
\text { school-level }\end{array}$ & 2SLS \\
\hline \multirow[t]{2}{*}{ POLYTECHNIC } & $0.036^{*}$ & -0.012 & 0.082 & 0.023 & 0.006 & 0.020 \\
\hline & $(0.019)$ & $(0.030)$ & $(0.069)$ & $(0.016)$ & $(0.024)$ & $(0.051)$ \\
\hline $\begin{array}{l}\text { Indicators for schools and } \\
\text { graduation years }\end{array}$ & Yes & Yes & Yes & Yes & Yes & Yes \\
\hline Other background characteristics & Yes & Yes & Yes & Yes & Yes & Yes \\
\hline Matriculation exam score & Yes & Yes & Yes & Yes & Yes & Yes \\
\hline Sample & Matriculated & Matriculated & $\begin{array}{l}\text { Matriculated } \\
\text { 1990-96 }\end{array}$ & Matriculated & Matriculated & $\begin{array}{c}\text { Matriculated } \\
\text { 1990-96 }\end{array}$ \\
\hline $\mathrm{N}$ & 5365 & 156 & 3989 & 3847 & 156 & 2839 \\
\hline $\mathrm{R}^{2}$ & 0.151 & 0.624 & 0.10 & 0.292 & 0.795 & 0.20 \\
\hline $\mathrm{N}$ excl. instruments & & & 140 & & & 134 \\
\hline Sargan test (p-value) & & & $165.2(0.07)$ & & & $155.8(0.10)$ \\
\hline Cragg-Donald F-statistic (p-value) & & & $1.45(0.00)$ & & & $1.51(0.00)$ \\
\hline Anderson-Rubin F-stat (p-value) & & & $1.18(0.07)$ & & & $1.15(0.12)$ \\
\hline
\end{tabular}

Panel B: Social and health care

(1)

(2)

(3)

(4)

(5)

(6)

\begin{tabular}{|c|c|c|c|c|c|c|}
\hline & Employed & Employed & Employed & Earnings & Earnings & Earnings \\
\hline & $\begin{array}{c}\text { OLS } \\
\text { indiv.-level }\end{array}$ & $\begin{array}{c}\text { WLS } \\
\text { school-level }\end{array}$ & 2SLS & $\begin{array}{c}\text { OLS } \\
\text { indiv.-level }\end{array}$ & $\begin{array}{c}\text { WLS } \\
\text { school-level }\end{array}$ & 2SLS \\
\hline \multirow[t]{2}{*}{ POLYTECHNIC } & $0.027^{*}$ & -0.002 & -0.113 & -0.014 & -0.009 & -0.044 \\
\hline & $(0.016)$ & $(0.028)$ & $(0.071)$ & $(0.012)$ & $(0.024)$ & $(0.044)$ \\
\hline $\begin{array}{l}\text { Indicators for schools and } \\
\text { graduation years }\end{array}$ & Yes & Yes & Yes & Yes & Yes & Yes \\
\hline Other background characteristics & Yes & Yes & Yes & Yes & Yes & Yes \\
\hline Matriculation exam score & Yes & Yes & Yes & Yes & Yes & Yes \\
\hline Sample & Matriculated & Matriculated & $\begin{array}{l}\text { Matriculated } \\
\text { 1990-96 }\end{array}$ & Matriculated & Matriculated & $\begin{array}{c}\text { Matriculated } \\
\text { 1990-96 }\end{array}$ \\
\hline $\mathrm{N}$ & 9587 & 165 & 8911 & 5498 & 164 & 5043 \\
\hline $\mathrm{R}^{2}$ & 0.080 & 0.751 & 0.03 & 0.143 & 0.686 & 0.08 \\
\hline $\mathrm{N}$ excl. instruments & & & 144 & & & 143 \\
\hline Sargan test (p-value) & & & $139.1(0.60)$ & & & $148.6(0.36)$ \\
\hline Cragg-Donald F-statistic (p-value) & & & $2.01(0.00)$ & & & $1.69(0.00)$ \\
\hline Anderson-Rubin F-stat (p-value) & & & $0.98(0.55)$ & & & $1.03(0.39)$ \\
\hline
\end{tabular}


Panel C: Business and administration
(1)
(2)
(3)
(4)
(5)

\begin{tabular}{|c|c|c|c|c|c|c|}
\hline & Employed & Employed & Employed & Earnings & Earnings & Earnings \\
\hline & $\begin{array}{c}\text { OLS } \\
\text { indiv.-level }\end{array}$ & $\begin{array}{c}\text { WLS } \\
\text { school-level }\end{array}$ & 2SLS & $\begin{array}{c}\text { OLS } \\
\text { indiv.- level }\end{array}$ & $\begin{array}{c}\text { WLS } \\
\text { school-level }\end{array}$ & 2SLS \\
\hline \multirow[t]{2}{*}{ POLYTECHNIC } & $0.226 * * *$ & $0.145^{* * *}$ & $0.156^{*}$ & $0.120 * * *$ & 0.034 & $0.203 * * *$ \\
\hline & $(0.016)$ & $(0.034)$ & $(0.088)$ & $(0.014)$ & $(0.030)$ & $(0.060)$ \\
\hline $\begin{array}{l}\text { Indicators for schools and } \\
\text { graduation years }\end{array}$ & Yes & Yes & Yes & Yes & Yes & Yes \\
\hline Other background characteristics & Yes & Yes & Yes & Yes & Yes & Yes \\
\hline Matriculation exam score & Yes & Yes & Yes & Yes & Yes & Yes \\
\hline Sample & Matriculated & Matriculated & $\begin{array}{c}\text { Matriculated } \\
\text { 1990-96 }\end{array}$ & Matriculated & Matriculated & $\begin{array}{l}\text { Matriculated } \\
\text { 1990-96 }\end{array}$ \\
\hline $\mathrm{N}$ & 10120 & 166 & 10832 & 5551 & 161 & 5246 \\
\hline $\mathrm{R}^{2}$ & 0.176 & 0.689 & 0.13 & 0.357 & 0.782 & 0.29 \\
\hline $\mathrm{N}$ excl. instruments & & & 148 & & & 143 \\
\hline Sargan test (p-value) & & & $146.3(0.52)$ & & & $159.3(0.17)$ \\
\hline Cragg-Donald F-statistic (p-value) & & & $1.40(0.00)$ & & & $1.22(0.02)$ \\
\hline Anderson-Rubin F-stat (p-value) & & & $0.97(0.60)$ & & & $1.16(0.10)$ \\
\hline
\end{tabular}

Notes: Columns 1 and 4 report separate OLS regressions in which each of the dependent variables (the probability of being employed at $t+1$ and the logarithm of annual earnings at $t+1$ conditional on being employed is explained with the indicators for schools and graduation years, and our variable of interest (POLYTECHNIC) that identifies a polytechnic degree. In Columns 1 and 4 other background characteristics of graduates (gender, age and its square, work experience and its square, mother tongue and earlier qualifications) and the sum of the best four exam scores in the matriculation examination are also controlled for. Columns 2 and 5 report separate WLS regressions in which each of the dependent variables (the share of employed at $t+1$ among those who have graduated from each school and the average level of graduates' log annual earnings at $t+1$ ) is explained with the indicators for schools and graduation years, and the variable (POLYTECHNIC) that identifies the share of polytechnic degrees taken in a school. In Columns 2 and 5 other background characteristics (gender, age, work experience, mother tongue and earlier qualifications) as shares of graduates are also controlled for and the average sum of the four best exam scores in the matriculation examination in each school is included among the explanatory variables. Columns 3 and 6 report our IV estimates, as explained in the text. Robust standard errors are reported in parentheses and significance is indicated by *** (1\%), ** (5\%), * (10\%). 
Appendix

Table A1. Descriptive statistics of the individual-level variables for the whole sample.

Variable

Source

Average

Standard deviation Min

Max

\section{Dependent variables in Table 1}

Employed ( $\mathrm{t}+1)$

Employed ( $(+2)$

Unemployed $(\mathrm{t}+1)$

Unemployed $(\mathrm{t}+2)$

Student $(\mathrm{t}+1)$

Student ( $(+2)$

$\begin{array}{lll}\text { ES } & 0.702 & 0.457 \\ \text { ES } & 0.748 & 0.434 \\ \text { ES } & 0.122 & 0.327 \\ \text { ES } & 0.089 & 0.285 \\ \text { ES } & 0.108 & 0.310 \\ \text { ES } & 0.096 & 0.294\end{array}$

\section{Dependent variables in Table 2}

Employed ( $\mathrm{t}+1)$, conditional on having annual ES earnings of at least $€ 8409$

Logarithm of annual earnings $(\mathrm{t}+1)$,

conditional on having annual earnings of at

Finnish tax

0.702

0.457

9.855

0.356

authorities

0.356

0.457

0.327

0.310

least $€ 8409$

Explanatory variable in Tables 1-2

Polytechnic degree

The Register of
Completed
Education and
Degrees

0.240

0.427

0

1

Degrees

Explanatory variables in Table 2

\begin{tabular}{lllllll} 
Female & ES & 0.660 & 0.474 & 0 & 1 \\
Age & ES & 25.937 & 3.676 & 18 & 35 \\
\hline
\end{tabular}




\begin{tabular}{|c|c|c|c|c|c|}
\hline $\begin{array}{l}\text { Work experience (the number of months five } \\
\text { years before graduation) }\end{array}$ & ES & 18.570 & 16.602 & 0 & 60 \\
\hline Mother language Swedish & ES & 0.048 & 0.213 & 0 & 1 \\
\hline $\begin{array}{l}\text { Mother language other than Finnish or } \\
\text { Swedish }\end{array}$ & ES & 0.011 & 0.105 & 0 & 1 \\
\hline Previous matriculation examination & $\begin{array}{l}\text { The Register of } \\
\text { Completed } \\
\text { Education and } \\
\text { Degrees }\end{array}$ & 0.657 & 0.475 & 0 & 1 \\
\hline $\begin{array}{l}\text { Previous secondary-level vocational school } \\
\text { qualification }\end{array}$ & $\begin{array}{l}\text { The Register of } \\
\text { Completed } \\
\text { Education and } \\
\text { Degrees }\end{array}$ & 0.315 & 0.464 & 0 & 1 \\
\hline Previous vocational college degree & $\begin{array}{l}\text { The Register of } \\
\text { Completed } \\
\text { Education and } \\
\text { Degrees }\end{array}$ & 0.109 & 0.311 & 0 & 1 \\
\hline Previous university degree & $\begin{array}{l}\text { The Register of } \\
\text { Completed } \\
\text { Education and } \\
\text { Degrees }\end{array}$ & 0.012 & 0.110 & 0 & 1 \\
\hline \multicolumn{6}{|c|}{ Explanatory variable in Table 3 (Columns 1 and 4 ) for the matriculated students } \\
\hline $\begin{array}{l}\text { The sum of the four best exam scores in the } \\
\text { matriculation examination }\end{array}$ & $\begin{array}{l}\text { The Register of } \\
\text { Completed } \\
\text { Education and } \\
\text { Degrees }\end{array}$ & 16.597 & 3.780 & 0 & 24 \\
\hline
\end{tabular}


${ }^{1}$ An English language overview of the Finnish education system can be found from the country background report for the OECD thematic review of tertiary education in Finland (Ministry of Education, 2005).

${ }^{2}$ These degrees are equivalent to the Bachelor of Arts (Hons) or Bachelor of Science (Hons) Degrees in the UK, the French Licence, the German Diplom Fachhochschule and the Dutch HBO Diploma.

${ }^{3}$ The average actual completion time was 3.9 years in 2004, according to the AMKOTA database that is used by the Ministry of Education to monitor the performance of polytechnic schools.

${ }^{4}$ The admission procedure during the reform was strictly regulated by the joint application system of the Ministry of Education. It was very explicitly stated in the guidelines that it was prohibited to change the admission criteria.

${ }^{5}$ Two polytechnics are not the mode of school choices for any of the upper secondary schools. Hence, the number of quasi regions is smaller than the number of polytechnics.

${ }^{6}$ The same lower earnings limit is used by Statistics Finland (2002) in the Income Distribution Survey to classify a person as a full-time full-year worker, based on annual data. Finland does not have a minimum wage law. However, our earnings limit is also close to the lowest trainee wage allowed in the union contracts.

${ }^{7}$ We have experimented by estimating multinomial logit models with three alternatives (being employed, being unemployed and continuing studies). The results are in accordance with those reported in Table 1 . Since the multinomial logit model is based on the IIA assumption, it does not allow some alternatives to be close substitutes either. 